\title{
Liquefied natural gas: could it be a reliable option for road freight transport in the EU?
}

\author{
Jose Luis Osorio-Tejada, Eva Llera-Sastresa ${ }^{*}$, Sabina Scarpellini \\ CIRCE- Centre of Research for Energy Resources and Consumption, University of Zaragoza, Mariano \\ Esquillor, 15-E 50018 Zaragoza, Spain.
}

\begin{abstract}
Approximately one-quarter of the total greenhouse gases (GHG) emissions in Europe can be attributed to the transport sector, with petroleum-derived fuels dominating road transport. In the current environmental and economic context, the use of less polluting alternative fuels simultaneously providing security of supply and optimal energy storage is encouraged. Natural gas (NG) technology for transportation is mature and extended through the use of the compressed form in urban and light vehicles. The introduction of liquefied natural gas (LNG) could broaden the use of natural gas for longer distances due to its higher energy density. In addition, the use of LNG in heavy-duty vehicles reduces the GHG emissions per kilometer by up to $20 \%$ and eliminates almost $100 \%$ of the sulfur oxides and particulate matter while also reducing the noise in inner cities compared with the use of diesel trucks. This paper reviews the key environmental, technical and socioeconomic aspects of LNG deployment as alternative fuel for road freight transport. Although it is necessary to continue research to develop a reliable database to estimate the actual environmental impact of LNG, the main difficulties for its deployment are market-related. From this market perspective, the prospects for LNG introduction in the European scenario have also been analyzed. Ensuring price stability and reducing uncertainty for investments are keys. Steps taken to date for developing an open and transparent international NG market are paving the way. In addition, the installation of new LNG terminals would significantly contribute to the security of supply and meeting diversification targets. Finally, some projections for the LNG implementation in the Spanish road freight transport are introduced, concluding that the fuel switch in long-haul trucks could reduce GHG emissions by $12 \%$ and diesel fuel consumption by $42 \%$ in the long term.
\end{abstract}

Keywords: LNG, Freight transport, heavy-duty vehicle, alternative fuel.

\section{Introduction}

In 2013, the European transport sector (EU-28) released 24.4\% of the region's total greenhouse gases (GHG) emissions [1], with $94.6 \%$ of these emissions provided by road transport [2]. Within this transport mode, the use of gasoline and diesel yielded 98\% of the GHG emissions [2].

These statistics are very similar to those of other Northern hemisphere countries, and many have recently intensified their search for economical and cleaner fuels for the transport sector. Hydrogen $\left(\mathrm{H}_{2}\right)$, biofuels,

Abbreviations: CI, Compression ignition; CNG, Compressed natural gas; CO, Carbon monoxide; $\mathrm{CO}_{2}$, Carbon dioxide; GHG, Greenhouse gases; $\mathrm{H}_{2}$, Hydrogen; HD-UDDS, Heavy duty urban dynamometer driving schedule; HDV, Heavy-duty vehicle; HPDI, High-pressure direct injection; LNG, Liquefied natural gas; NG, Natural gas; NMVOC, Non-methane volatile organic compounds; $\mathrm{NO}_{\mathrm{x}}$, Mono-nitrogen oxides; PM, Particulate matter; SI, Spark ignition; $\mathrm{SO}_{\mathrm{x}}$, Sulphur oxides; SSL, Small scale liquefaction; TTW, Tank-to-wheels; WTT, Well-to-tank; WTW, Well-to-wheels.

* Corresponding author. Tel.:+34 976762951

E-mail address: ellera@unizar.es (Dr. Eva Llera) 
electricity, natural gas (NG), and synthetic fuels from coal, among others, have been identified as the most relevant for road vehicles [3-9], although some limitations have also been identified.

For example, even though $\mathrm{H}_{2}$ can significantly reduce GHG emissions, its use in electric (with fuel cells) or internal combustion engines faces high production costs and low fuel density, requiring large investments to maintain the security and achieve acceptable energy storage [10]. In this context, the $\mathrm{H}_{2}$ production costs, depending on the process, are expected to be reduced by $30 \%$ to $50 \%$ before 2050 [11]. In addition to the environmental impact of the use of electricity for transport being highly dependent on the power sources, battery electric vehicles show additional shortcomings related to the time for recharging, the low autonomy, and the high battery cost and mass. Although battery costs have decreased by $14 \%$ annually since 2007 [12], it is still necessary to continue investment in R\&D to develop costeffective and high energy density batteries to improve the competitiveness of electric vehicles with conventional ones. For these reasons, electric vehicles are generally suitable for only urban use or short distances [13]. In the case of biofuels, especially bioethanol and biodiesel, the main problem is their limited availability. Therefore, the EU recommended using other alternative fuels until advanced biofuels are commercially available on a large scale [14]. Advanced or next-generation biofuels include those generated from algae, waste or non-food biomass that do not affect arable land; e.g., BTL (biomass-toliquid) fuel, which has similar properties to diesel oil and is produced from lignocellulosic sources [15]. Currently, the biofuels outlook is uncertain, with some companies announcing new projects in 2014, but many others cancelling projects in recent years [12], mainly due to the low oil prices. Biogas produced from biomass or waste (biomethane) or synthetically (e-methane) [16], also is limited and large-scale production for competitive prices is needed. Synthetic fuels from coal have high availability, but the methods that allow a cleaner life cycle such as carbon dioxide $\left(\mathrm{CO}_{2}\right)$ capture increase the costs of the final product. In the long term, if more efficient production processes are developed, gaseous fuels from coal could be used if the number of gas-powered vehicles increases considerably [6]. The technical viability of the use of the NG in vehicles has long been demonstrated. The use of NG in vehicles was introduced in Italy in 1930, and New Zealand took accelerated steps years later [17]. In other world regions, the number of NG vehicles has increased since 1980, especially in Latin America and Asia, where the main motivation has been the cost savings achieved by the indigenous natural gas use. In some of these countries, up to $20 \%$ of the entire fleet works with natural gas, whereas in the pioneer Italy, they constitute only $1.1 \%$ of the entire registered fleet [18]. The main restricting factors for natural gas use in vehicles are related to the resource availability and the existence of pipelines and a distribution infrastructure [19].

In 2001, the European Commission proposed a 20\% substitution of oil by alternative fuels in the road transport sector by 2020 to improve the security of the European energy supply and reduce the emissions of GHG [20]. At that time, the EU planned the introduction of biofuels in the short and medium term, natural gas in the medium and long term and hydrogen in the distant long term.

Although it was projected that biofuels would constitute at least $6 \%$ of the road transport fuels by 2010 [20], the value reached only $4.4 \%$ in that year, mainly due to the strong competition with agriculture and land use [14]. Currently, biofuels share approximately 5\%. Due to difficulties faced in expanding their application, the EU aims to maintain this percentage while encouraging the use of other alternative sources [21].

The recent EU strategy for alternative fuels $[11,14]$ is to prioritize mature technologies for each need. Based on its maturity and economic viability, NG is still reported by the European Union (EU) to be one of the best alternatives for road transport in the short to medium term to reduce the environmental impact and reach the objective of fuel diversification in road transport [14].

NG use has recently been extended by the compressed natural gas (CNG) application in light spark ignition engines for urban use. However, the limited autonomy of CNG vehicles would require the installation of a refueling station at least every $150 \mathrm{~km}$, as was recommended in Directive 2014/94/EU on the deployment of an alternative fuels infrastructure [22], which has been difficult to implement due to the low demand for NG vehicles in the Member States. The European Parliament and the Council, with their Directive 2014/94/EU, regarding the Commission communication 'Clean Power for Transport', set deadlines for Member States to define regulations and ensure an appropriate number of refueling stations for road vehicles. Among these targets, the above Directive sets a deadline of the end of 2020 for the installation of electrical and CNG stations in urban and suburban densely populated areas. For the installation of liquefied natural gas (LNG) stations through roads and ports that connect the TransEuropean Network for Transport (TEN-T Core Network) to supply heavy-duty vehicles (HDVs) and for $\mathrm{H}_{2}$ stations, for those Member States that decide to include them, the deadline is the end of 2025. Likewise, the EU aims for these NG stations to receive biogas blends produced locally to decrease the carbon intensity in the fossil natural gas [22]. 
Due to its energy density, LNG is presented as the solution to the autonomy and infrastructure obstacles for long distance-road transport (a LNG vehicle with the same fuel tank size could travel up to 2.4 times the distance compared with one fueled by CNG [18,23]) and the only viable and mature alternative for diesel substitution [14].

This paper aims to analyze the key aspects for the introduction of LNG in the European transport sector, including both the technological and market aspects, and to highlight the benefits of the LNG trade in the NG market with respect to de-regionalization and energy security in the EU.

Some projections for LNG implementation in Spanish road freight transport are to obtain approximations related to the environmental impact and the diesel dependency reduction in the long term.

\section{Analysis of LNG as fuel for road freight transport}

As summarized below in Table 1, some studies have considered LNG introduction in road transport, taking into account technical, economic and/or environmental aspects. Most of these studies have been performed in countries outside of the EU, especially in North America.

Table 1

Literature review related to LNG application in road freight transport.

\begin{tabular}{|c|c|c|c|c|c|c|}
\hline Reference & & Opinion $^{\mathrm{a}}$ & & Year & Remarks & Country \\
\hline & $\underset{b}{\text { Technical }}$ & Socioeconomic & Environmental $^{C}$ & & & \\
\hline Frailey [24] & $+/-$ & & & 1998 & $\begin{array}{l}\text { On-road test. Difficulties with the LNG fuel station } \\
\text { precluded the accomplishment of all planned tests. }\end{array}$ & US \\
\hline $\begin{array}{l}\text { Litzke and } \\
\text { Wegrzyn [25] }\end{array}$ & + & - & & 2001 & $\begin{array}{l}\text { The LNG technology costs are not attractive to fleet } \\
\text { owners yet. }\end{array}$ & US \\
\hline Beer et al. [5] & & & - & 2002 & $\begin{array}{l}\text { The extra energy required in the WTT analysis } \\
\text { increases the total GHG emissions }\end{array}$ & Australia \\
\hline $\begin{array}{l}\text { Kevin } \\
\text { Chandler [26] }\end{array}$ & + & $+/-$ & & 2004 & $\begin{array}{l}\text { On-road tests. The maintenance cost is higher than that } \\
\text { of diesel trucks. }\end{array}$ & US \\
\hline $\begin{array}{l}\text { Peredel'skii et } \\
\text { al. [27] }\end{array}$ & + & + & & 2005 & $\begin{array}{l}\text { A technical and economic description for the Russian } \\
\text { case }\end{array}$ & Russia \\
\hline $\begin{array}{l}\text { Rideout and } \\
\text { Hendren [28] }\end{array}$ & + & & + & 2006 & $\begin{array}{l}\text { Chassis dynamometer test. A TTW analysis of the HD- } \\
\text { UDDS cycle }\end{array}$ & Canada \\
\hline CARB [29] & + & & + & 2008 & $\begin{array}{l}\text { TTW data by own tests and WTT data from the } \\
\text { GREET model from the ANL [30] }\end{array}$ & US \\
\hline $\begin{array}{l}\text { Rosenfeld and } \\
\text { Jackson [31] }\end{array}$ & + & & + & 2008 & $\begin{array}{l}\text { TIAX LLC. A WTW analysis based on WTT from } \\
\text { ANL [30] and TTW from Rideout and Hendren [28] }\end{array}$ & Canada \\
\hline $\begin{array}{l}\text { Fedorova et al. } \\
\text { [23] }\end{array}$ & + & & + & 2009 & $\begin{array}{l}\text { Technical and chemical analysis of the use of LNG as a } \\
\text { fuel. Only a TTW analysis }\end{array}$ & Russia \\
\hline $\begin{array}{l}\text { Kumar et al. } \\
{[18]}\end{array}$ & + & + & + & 2011 & General review & $\begin{array}{l}\text { South } \\
\text { Korea }\end{array}$ \\
\hline $\begin{array}{l}\text { Andress et al. } \\
\text { [3] }\end{array}$ & & + & $+/-$ & 2011 & $\begin{array}{l}\text { WTW data from ANL [30]. LNG encourages fuel } \\
\text { diversification and an imported oil demand reduction }\end{array}$ & US \\
\hline $\begin{array}{l}\text { Meloche et al. } \\
\text { [32] }\end{array}$ & + & & $+/-$ & 2013 & $\begin{array}{l}\text { Chassis dynamometer tests. The fuel consumption and } \\
\text { the emissions depend on the driving cycle. }\end{array}$ & Canada \\
\hline $\begin{array}{l}\text { Cheenkachorn } \\
\text { et al. [33] }\end{array}$ & $+/-$ & + & + & 2013 & $\begin{array}{l}\text { Chassis dynamometer test. The maximum amount of } \\
\text { NG to avoid a significant loss of efficiency is } 77.9 \% \text {. }\end{array}$ & Thailand \\
\hline $\begin{array}{l}\text { Arteconi et al. } \\
{[34,35]}\end{array}$ & + & + & + & 2013 & $\begin{array}{l}\text { A technical, economic and environmental study in } \\
\text { Italy. TTW data from Rideout and Hendren [28] }\end{array}$ & Italy \\
\hline Ma et al. [36] & + & $+/-$ & + & 2013 & A review from Chinese sources and Arteconi et al. [35] & China \\
\hline ANL $[30,37]$ & + & + & + & 2014 & $\begin{array}{l}\text { Based on own tests and national sources. They argued } \\
\text { that a three-year payback of new trucks is favorable }\end{array}$ & US \\
\hline DLR et al. [38] & $+/-$ & $+/-$ & $+/-$ & 2014 & $\begin{array}{l}\text { LNG engines are less efficient, and the emissions } \\
\text { exceed 10\% in the WTW analysis. (WTT data from } \\
\text { JEC [39]) }\end{array}$ & Germany \\
\hline DENA [16] & + & + & $+/-$ & 2014 & $\begin{array}{l}\text { They expect that after 2015, the new LNG trucks will } \\
\text { have } 10 \% \text { GHG savings in the WTW analysis. }\end{array}$ & Germany \\
\hline DTTL [40] & + & + & + & 2014 & $\begin{array}{l}\text { General study about the NG introduction in all } \\
\text { transport modes in Spain. }\end{array}$ & Spain \\
\hline
\end{tabular}

\footnotetext{
a Authors' standpoint about the LNG success in road freight transport: (-) no good results; $(+)$ positive results; (+/-) neutral or doubtful.

${ }^{\mathrm{b}} \mathrm{A}(+)$ means that the LNG performance and fuel economy are almost the same or better than those of diesel trucks.

${ }^{c}$ Only considers the GHG emission reduction, because all studies agree with the $\mathrm{PM}^{\mathrm{and}} \mathrm{SO}_{\mathrm{x}}$ elimination and $\mathrm{NO}_{\mathrm{x}}$ reduction results
} 


\subsection{Environmental aspects}

The environmental advantages lie in the LNG production process itself. During the LNG production, the natural gas is dehydrated and cleaned of hydrocarbons, $\mathrm{CO}_{2}$ and sulfur [36], obtaining high-purity methane (98\%) that is then cooled to $-162{ }^{\circ} \mathrm{C}$, becoming a liquid and reducing its volume by approximately 600 times. Due to the high purity of the LNG, air pollutants, i.e. toxic engine emissions that can cause respiratory diseases in humans and animals as well as defoliation in plants [42,43], are lower than those of traditional fuels: approximately $80 \%$ for carbon monoxide (CO), $70 \%$ for mononitrogen oxides $\left(\mathrm{NO}_{\mathrm{x}}\right)$ and $45 \%$ for non-methane volatile organic compounds (NMVOCs), whereas the reductions of sulphur oxides $\left(\mathrm{SO}_{\mathrm{x}}\right)$ and particulate matter $(\mathrm{PM})$ are greater than $97 \%[18,23]$. Therefore, LNG trucks can seamlessly fulfil the Euro VI standard without requiring after-treatment exhaust equipment, as is required by diesel trucks.

However, there is no agreement about the environmental benefits of the LNG. The origin of these discrepancies is the stage of the whole LNG life cycle where the GHG emissions are measured. The life cycle assessment for fuels, which is known as well-to-wheels (WTW) analysis, comprises the well-totank (WTT) and the tank-to-wheels (TTW) analyses. The WTT analysis consists of the measurement of energy consumption and emissions during the fuel production, storage, transport and distribution, while the TTW analysis corresponds to such measurements during the fuel combustion in vehicles. In terms of energy consumption ( $\mathrm{g} \mathrm{CO}_{2}$-eq/MJ), the LNG TTW analysis shows reductions in GHG emissions of up to $25 \%$. However, as a result of the extra-energy needed for the liquefaction, transportation and distribution of LNG compared with diesel in the WTT analysis, the total GHG emissions reduction in the WTW analysis would be up to $16 \%[29,30,38,39]$.

Furthermore, LNG-fueled engines are less energy efficient than modern diesel-fueled compression ignition (CI) engines; in other words, LNG trucks consume more energy per kilometer. There are two types of LNG applications in vehicles. "Dual fuel" is a CI engine fueled by 90-95\% LNG blended with a small quantity (5-10\%) of diesel that acts as pilot whose efficiency is $5 \%$ lower than that of a dieselfueled CI engine, whereas "dedicated" is a spark ignition (SI) engine fueled by $100 \%$ LNG, with an efficiency between $10 \%$ and $30 \%$ lower than that of a diesel-fueled CI engine [16,41]. Hence, in the TTW analysis, the reduction of GHG emissions per kilometer is up to $20 \%$ [4,28-31,44], whereas the WTW analysis can show both reductions and increases up to $10 \%$, that is to say, a variation between $-10 \%$ to $10 \%$ in total GHG emissions per kilometer compared with the diesel emissions [5,30,35].

In most cases, the GHG emissions decrease in terms of the energy consumed by LNG trucks, but in terms of the distance travelled, LNG trucks could not achieve reductions or even emit more than the new diesel trucks. Currently, there are no predetermined emission factors to estimate how much GHG will be emitted by a certain type of LNG-fueled truck running on a specific road. This is because emissions depend on variables such as the engine and local temperature, altitude above sea level, engine condition and mileage, emission control technology, fuel purity, and driving mode, as well as the vehicle load, which can increase the exhaust emissions by approximately 45\% [45]. For these reasons, diverse studies have reported different reduction rates related to the GHG emissions per kilometer for the TTW analysis, as well as for the WTT analysis due to the varied methods of disposing of the LNG in the refueling stations, e.g., imported or indigenous NG and pipeline or trucking distribution. A WTW analysis compilation from the literature, considering only LNG imported by sea and carried from the regasification terminal to the LNG station by tanker truck, is illustrated in Fig. 1. 


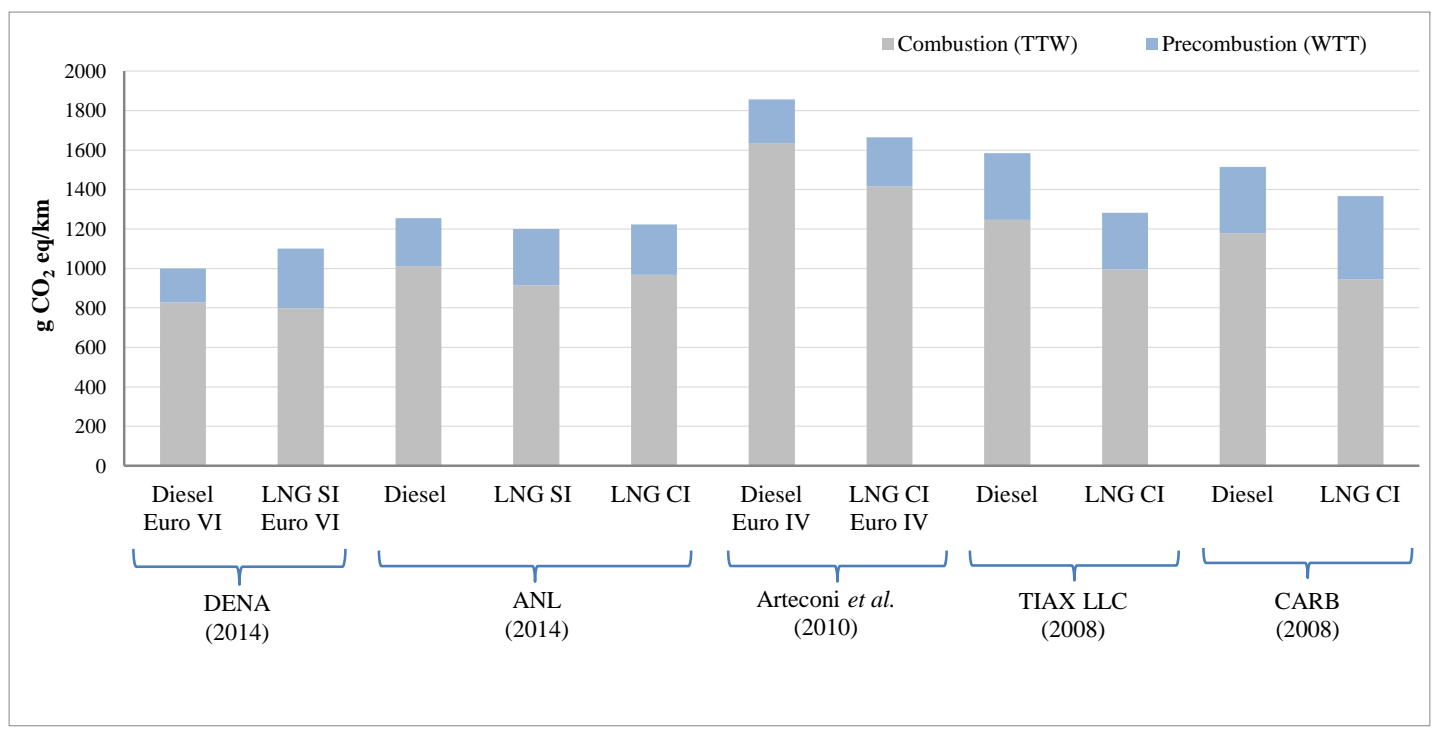

Fig. 1. Life-cycle GHG emissions comparison in LNG and diesel HDVs. Sources: [16,29-31,35,38].

In most studies, the GHG emitted by diesel trucks exceeds that of LNG trucks in the WTW analysis, with the exception of the German Energy Agency’s (DENA) report, where that of LNG trucks exceeds that of diesel trucks [16]. This trend in the DENA report is basically due to the emissions during the LNG production and transportation from Qatar to Zeebrugge in Belgium (13,000 km) by vessel and to the LNG station in Germany by tanker truck $(500 \mathrm{~km})$ [38], whereas the total average distance considered in the Italian analysis by Arteconi et al. [35] for the EU was less than half.

Another particularity in Fig. 1 is the origin of the TTW emission factors, where DENA adopted the data from the German consultancy Ludwig Bölkow Systemtechnik (LBST), whereas the other 4 sources obtained data from North American experiments, even the Arteconi et al. [35] analysis, which extracted the emission factors from a chassis dynamometer test performed in 2006 in Canada [4,28].

Although GHG reduction is not significant, in the medium to long term, the development of infrastructure for fossil natural gas distribution and an important LNG fleet could contribute to the introduction of biogas, e.g. using liquefied synthetic methane, produced by synthesis of $\mathrm{CO}_{2}$ and $\mathrm{H}_{2}$ with renewable electricity (Power-To-Gas), or liquefied biomethane, the GHG emissions per kilometer could decrease up to $92 \%$ and $62 \%$, respectively [16].

\subsection{Technical aspects}

In general, the use of LNG in road freight transport is technologically optimal. LNG trucks show the same or better performance and fuel efficiency than new diesel trucks. Likewise, the high energy density of LNG in HDV has been demonstrated in different experiments, e.g., a dump truck with a LNG 560-liter fuel tank stores the equivalent of 25 to 27 CNG cylinders, saving $2000 \mathrm{~kg}$ of carrying capacity [27]. Lu et al. [46] reported that an LNG bus in Beijing with a 335-liter fuel tank could travel $450 \mathrm{~km}$ without stopping to recharge, and Zhou et al. [47] affirmed that an LNG truck for freight transport between the U.S. and Canada with a 680-liter fuel tank could travel $800 \mathrm{~km}$. Currently, different manufacturers offer trucks with LNG dual fuel or dedicated engines with autonomies of up to $1100 \mathrm{~km} \mathrm{[16].}$

The application of LNG in vehicles is supported by the mature technology for natural gas combustion because, in CNG and LNG vehicles, the fuel is always injected into the engine in gaseous form. Thus, the main difference between the two types of vehicles is the fuel storage method. In a LNG vehicle with either a CI or SI engine, according to Lu et al. [46], the cryogenically stored natural gas is preheated and vaporized in a heat exchanger (usually with the engine radiator fluid) before being injected in gaseous form to the cylinders for burning at a temperature between $-40^{\circ} \mathrm{C}$ and $90{ }^{\circ} \mathrm{C}$ [36].

In 1998, Frailey [24] performed tests in modified dual-fuel LNG trucks with the gas injection system available at that time, which consisted of a mixer connected to the air inlet duct, injecting air enriched with NG into the cylinders. Because this injection method is difficult to control due to variable atmospheric conditions, the NG trucks did not work efficiently. Over the years, the injection methods used in the design of NG electronic injectors for SI engines improved thanks to the high demand in urban light vehicles. This market maturity has encouraged the use of LNG in SI engines for HDVs, but limited 
to those with less than 400 horsepower. Several manufacturers currently sell new dedicated LNG Euro VI trucks with energy efficiency equal or superior to those that are gasoline-fueled. However, these trucks are up to $30 \%$ less efficient than modern common rail diesel engines [16,41]. Nevertheless, thanks to their low technology and fuel costs, dedicated LNG trucks can compensate for their low efficiency.

The most promising technology to obtain the energy efficiency and performance of modern diesel engines, as well as significant GHG reductions, is the high-pressure direct injection (HPDI) system developed by Westport Power, Inc. This technology uses the fuel pressure from the LNG storage tanks and a fuel pump to send high-pressure NG through dual-concentric needle injectors into cylinders along with a small amount of diesel to increase the cetane number that ignites the NG in a CI engine, without power restrictions $[16,26,48]$.

During the past decade, the Westport HPDI technology has been tested in demonstration projects where drivers have reported that LNG trucks had as good as or better performance than diesel trucks $[25,26,28,31]$. In 2001, the technology achieved optimal results, but the high equipment costs precluded its commercial introduction [25]. By 2004, in demonstration tests supported by the U.S. Department of Energy and Cummins Westport, Inc., the prototype LNG dual fuel trucks with an HPDI system showed an energy equivalent fuel economy approximately $10.5 \%$ lower than that of diesel trucks, whereas in similar tests, the dedicated LNG engines had fuel economies between $27 \%$ and $37 \%$ lower than those of diesel trucks [26]. Although optimal results were achieved in the HPDI system, the manufacturers decided to continue developing the technology to improve the efficiency and decrease costs until the market was prepared to receive it by 2008 [26]. Although most comparison tests between LNG dual fuel trucks and diesel trucks in recent years have produced optimal results, there are studies that have concluded that the results depend on the driving cycle tested. In 2013, in a transient Heavy-Duty Urban Driving Dynamometer Schedule (HD-UDDS) cycle because of the slower average speeds and increased idling the LNG dual fuel HPDI engine obtained poor energy efficiency results [32]. In the same year, Cheenkachorn et al. [33], in another test with an unspecified LNG dual-fuel injection system, concluded that the maximum amount of LNG to maintain the same performance as a single diesel-fueled engine is $77.9 \%$.

After refining their experimental and demonstration tests, Westport Power, Inc. has developed 2nd generation HPDI technology to be introduced in 2015, allowing the engine to use up to 95\% LNG with an identical torque and fuel efficiency to the newest diesel fuel engines, in addition to having $20-25 \%$ lower GHG emissions [16,49].

\subsection{Socioeconomic aspects}

LNG use, in addition to the environmental benefits, can diversify the fuel used for road transport, where diesel is used in almost $100 \%$ of trucks, thereby reducing the imported oil demand [3] and contributing to energy security [41] in nations with scarce energy resources such as the Member States of the EU. Furthermore, the lower operational costs of LNG trucks due to the fuel being less expensive than diesel oil can improve transport companies' competiveness. Another benefit is the improvement of the quality of life for people and animals because LNG trucks produce low amounts of noise and air pollutants [13].

\subsubsection{Truck technology costs}

For LNG use in road freight transportation, owing to the low LNG fuel prices, high annual mileage and current technology costs for both new trucks and retrofitting kits for SI and CI engines, fleet owners can recover their investments in attractive periods. This scenario was unthinkable 15 years ago, when both the injection system and the storage tank were very expensive, and the maintenance costs were twice as high because the technology was in the prototype stage [26]. Likewise, the technologies to provide LNG as a fuel at service stations were not as developed as they are now, so LNG refueling was not less expensive than that of diesel oil [25].

Despite the current low oil price trend, the LNG price at service stations can be found to be lower than that of diesel oil in most Member States. For example, in the Netherlands, a real-life comparative study is in progress between 161 LNG dedicated trucks and diesel Euro VI trucks run on Dutch roads. The preliminary results show that the average LNG consumption is $25.3 \mathrm{~kg} / 100 \mathrm{~km}$ per truck, i.e., $26.21 €$, whereas the equivalent diesel truck consumes $32 \mathrm{~L} / 100 \mathrm{~km}$, i.e., $39.34 €$, that is, a fuel cost savings of approximately $30 \%$ [44]. In Spain, where the fuel cost savings are similar to those in the Dutch case, transport companies, which had 306 LNG trucks by the end of 2014 [50], reported a payback between 1 to 2 years, where the average incremental cost for a LNG dedicated truck is $30000 €$ and that of a retrofitted dual fuel truck is approximately $15000 €$ [40]. In other countries such as the U.S., where there 
are approximately 3600 LNG trucks, a recent study found that the payback would be less than 3 years, with shorter periods for the dual fuel trucks than for the dedicated ones due to the better energy efficiency [41]. In China, for retrofitted engines, the payback is less than 2 years, according to estimations made in 2013 [51].

\subsubsection{LNG supply at service stations}

By mid-2015, the EU had only 51 LNG stations, with 60\% of them in Spain and the Netherlands[50]. One of the factors causing the slow growth of LNG use in HDVs is the lack of refueling stations. Some surveys suggested that people would be interested in natural gas vehicles if between $10 \%$ and $20 \%$ of conventional stations would offer NG [19].

Without government intervention, the number of LNG stations will grow as the market for LNG-powered vehicles increases, and vice versa, falling into the chicken-egg problem that has challenged the spread of alternative fuels [41].

For the LNG supply in stations, there are two options: liquefaction "in situ", namely, small scale liquefaction (SSL) near to the service station using NG from a pipeline, or carrying the LNG by tanker trucks from a regasification terminal to the service station, which has been considered the more profitable option in many studies [34,36].

LNG is commonly sold in kilograms, being difficult to compare it with diesel pump prices directly. Likewise, if both fuels are sold per liter, they could not be comparable because of the energy content differences; LNG 21MJ/L and diesel 35.8MJ/L [34]. For these reasons, in Fig. 2, a comparison in energy terms between diesel and LNG pump prices based on costs estimations described in [34] and [52] and the update to 2015 is presented.

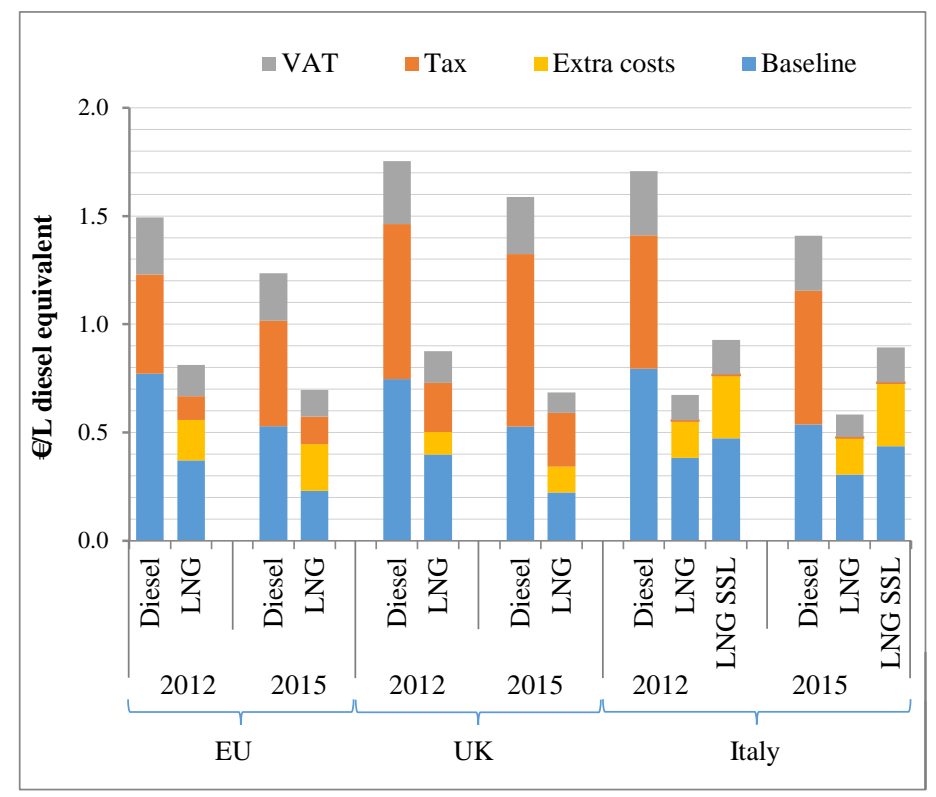

Fig. 2. Diesel and LNG costs breakdown

Although the oil price has dropped around 50\% between 2012 and 2015, the price of imported LNG has also been reduced by approximately $45 \%$ in the EU in the same period [52,53]. The LNG-diesel price gap at service stations in the EU has not been significantly affected due to the tax treatment in most Member States, where taxes (excise duty) for diesel are higher than its baseline price and taxes for natural gas are relatively much lower [54]. In Italy, the low rates charged to natural gas make the LNG pump price up to $60 \%$ lower than the diesel price, even considering higher extra costs than other countries because LNG is carried from the regasification terminal located in Barcelona. The price of LNG produced by SSL in Italy would be $37 \%$ below the diesel pump price. The considered extra costs are the additional costs and margin for LNG shipping, storing and handling or the liquefaction costs in the respective case [34,52].

The average LNG-diesel price gap in the EU is about $44 \%$, while in the UK the price gap increased from $50 \%$ in 2012 to $57 \% 2015$ due to the strong reduction of the LNG baseline price and the diesel tax increase. Diesel tax has remained steady [54] while the Euro's devaluation against the British Pound has allowed for the diesel pump price to be reduced by only 10\%. These trends showed in Fig. 2 seem 
favorable for the introduction of LNG considering that CNG has been successful in countries where the price is $40-60 \%$ lower than the gasoline price [19]. In addition, LNG estimated landed prices in 2016 might be up to $40 \%$ below the 2015 prices [53].

Another advantage is that because of the higher density of LNG than of CNG, the LNG station does not need a gas compressor, enabling it to be more compact and less noisy, and the refueling time is only $1 / 3$ to $1 / 5$ of that of CNG vehicles [36]. Compared to diesel stations, the time to refuel LNG is similar, but drivers require specific training and protective clothing, especially gloves to avoid cold-burns [38]. Despite the special cryogenic conditions in LNG stations, current technologies fulfill appropriate safety standards. Even LNG can be safer than diesel at stations [55] due to the absence of boil-off gases released to the environment as during the diesel refueling procedure. To remove the barrier of limited LNG stations, in addition to promoting the installation of alternative fuel stations by the TEN-T program, the EU has also created specific projects such as the LNG Blue Corridors with the target of building 14 new LNG stations and a fleet of 100 LNG trucks for operating along these corridors [56]. Additionally, in the near future, the Mediterranean Sea will become an Emission Control Area, where ships must use cleaner fuels to reduce emissions. LNG is among the most feasible alternatives, so it will be necessary to develop an LNG infrastructure in ports to encourage the use of this fuel for freight trucks [34].

Although the introduction of LNG as a substitute for diesel would threaten traders of this traditional fuel, for many of these companies, LNG is an opportunity to expand their market, incorporating LNG in its product portfolio. LNG consumers would benefit from refueling in habitual points, as well as the expertise of these companies would be helpful for installing new stations, being important for the longterm sustainability of these business models for alternative fuels.

\subsubsection{Impact on urban delivery}

Urban planning administrators perceive urban freight transport negatively because trucks affect the mobility and the infrastructure and pollute the city. Although HDVs represent only $10 \%$ of the vehicles operating in urban areas, they generate more than $40 \%$ of the emissions and noise [57]. The World Health Organization stated that noise is the second problem after the toxic emissions generated by vehicles [58]. Thus, local governments set restrictions to prevent delivery trucks from running in certain areas or during peak hours. The restrictions include time windows, access restrictions (by type of vehicle, emissions factor, size or mass), special zones for parking, charge systems (tolls or limited entry), early/night deliveries, special urban planning conditions and alternative delivery methods [59]. Some companies comply with the time windows to deliver during the day hours but this reduces the efficiency due to the higher number of trips made at different times with partial loads [60]. Companies also may increase their fleet size using smaller vehicles, but these vehicles require many person-hours and making multiple trips to the same place, increasing emissions, fuel consumption and congestion [61]. Therefore, an alternative to bring many goods to one place, e.g., supermarkets, large factories or distribution centers, is to use a large capacity truck during the night.

Night delivery would enhance the efficiency and decrease the congestion and noise during peak hours. However, night delivery is in conflict with regulations regarding noise [62,63]. In Spain, in most cities, night distribution is prohibited except in specific cases with special and very restricted permits [64]. It is here where natural gas trucks have an advantage over conventional trucks, as due to their high octane number, methane has a high resistance to auto-ignition, which increases the compression ratio, generates great thermal efficiency $[62,65,66]$, and reduces the engine noise by $50 \%$ compared with diesel combustion [67-69]. Therefore, the use of NG-fueled buses and trucks can reduce both the pollutant emissions and noise in urban areas [13]. The ban on delivery trucks at night in Spanish cities has motivated transport companies to equip their fleets with NG-powered engines to deliver to supermarkets at nights using special permits from city councils [70].

\section{Prospects for LNG introduction in the EU scenario}

As previously mentioned, the use of LNG for road freight transport presents undeniable strengths compared with diesel oil such as lower fuel costs, acceptable autonomy, lower emissions (in terms of $\mathrm{SO}_{\mathrm{x}}, \mathrm{PM}$ and $\mathrm{NO}_{\mathrm{x}}$, without requiring after-treatment exhaust equipment), lower noise and mature application technology. Nevertheless, the main weaknesses are the medium to high cost of the technology, especially in the case of dual fuel engines, and the modest GHG emissions reduction due to 
the leakage of methane and the extra energy required during the LNG life cycle. In addition, the introduction of LNG faces challenges to its widespread commercial introduction, including the absence of regulations for the installation of service stations, restrictions in some countries on LNG use in vehicles, the diesel price decline and the risk of shortages of imported natural gas that would immediately increase the LNG price in Europe.

Although, there are countries that have more experience with LNG-fueled trucks, such as China and the U.S., that have not experienced these problems, these countries have had a slow introduction of this technology. In these countries, the main barriers for the widespread commercial introduction of a new alternative fuel in road freight transport are market failures and externalities that do not give customers the ability to rely on LNG-fueled trucks in their fleets [71,72].

There have been isolated and quite recent LNG demonstration tests on performance and emissions (TTW) in private fleets in the EU [38,73], but there has been no comprehensive analysis to facilitate their mass introduction. Although it is necessary to continue research to develop a reliable database to estimate the actual environmental impact of LNG, the main difficulties for the deployment of LNG-fueled trucks are market related.

The next sections analyze the prospects for LNG introduction in the EU scenario from a market perspective.

\subsection{European natural gas market}

For many years, the world natural gas market has been more regional in character than that of oil. The traditional NG shares are transported in compressed form by pipelines to consumers. The nature of the CNG pipelines, with limited delivery points, precludes the internationalization of the NG market. Nonetheless, in recent years, LNG has played an important role in the integration of the NG markets, enabling delivery to several points, as LNG regasification terminals are easier to install in ports than pipelines and allow receiving LNG from diverse suppliers, avoiding dependence on a single supplier through pipelines. Recent studies suggest that the LNG trade is the major contributor to the global price integration, but in some regions where LNG cannot go and there is only CNG reception by pipeline, it continues to be a regional commodity [74,75].

LNG trade around the world has the advantage of there being no statistical relationship with the distance transported, whereas the CNG trade is strongly affected by the distances between countries. Barnes \& Bosworth [75] found that upon doubling the distance between countries, the CNG trade decreases 9 times. For that reason, the CNG trade is more regional, whereas LNG is considered an international product, and wherever LNG could be introduced, it would contribute to the de-regionalization of the market, increasing the diversity and consequently the security of the supply.

For more than 40 years, the NG price has been indexed to the oil price to link it with the highly liquid and transparent world oil market, avoiding volatility and conspiracy in regions with few suppliers. However, although the oil market has many suppliers in different parts of the world, due to the association of petroleum-exporting countries, the oil price has not been completely a "market price", which in ideal conditions should be established by the interaction of the supply and demand. For that reason, in recent years, an option to delink the NG and oil prices is the use of trading hubs, which are injection and extraction points in a gas network where owners exchange NG at a determined price level. The EU has supported the development of these trading hubs to develop a free and transparent NG market, in contrast to confidential negotiations based on oil-indexed NG prices [76].

Although the trading hubs could delink the oil-indexed NG prices, the regional nature of the NG pipelines does not allow market interaction under ideal conditions in some countries due to the limited number of suppliers.

As a result, the EU has encouraged the construction of LNG regasification terminals to create new trading hubs in ports where there is no NG pipeline network. In the past 4 years, the large quantity of LNG that has entered the European market has established competitive price levels in trading hubs, forcing the renegotiation of long-term oil-linked contracts with large operators [76]. This situation has converted the NG trade into an open international market, which seems to be more transparent than the oil market due to the diversity of independent NG suppliers. This scenario would ensure the price stability in both oil and NG products that can provide security in fuel cost savings for truck owners and reduce the uncertainty in investments.

Despite expectations of lower prices of LNG in the EU with the increase in supply from the U.S. and Australia [77], it is uncertain that the price gap between LNG and diesel will remain in the long term, which would narrow due to tax policy decisions and the diesel traders' influence. On one hand, the favorable tax treatment for LNG retail prices in the EU could disappear because fuel taxes are important revenue sources in most of the Member States [52]. On the other hand, the replacement of diesel by LNG 
could lead to a further reduction in diesel prices, especially in countries with a highly concentrated petroleum fuels market. Therefore, a high rate of introduction of LNG could equalize the prices of LNG and diesel at refueling stations, removing the operational cost advantage of switching to LNG. Similarly, if oil prices remain low in the coming years, LNG prices could also be reduced, affecting the development of infrastructure projects because low LNG prices would not cover the capital costs of new plants [77].

\subsection{Security of supply}

The EU-28 has high energy dependency rates, which, in 2013, were $88.4 \%$ for crude oil and $65.3 \%$ for natural gas [78]. The natural gas imports in the EU depend on 2 main suppliers: 39.3\% from Russia and 29.8\% from Norway, both almost solely transported by pipeline [78].

In addition to the previously discussed technical and market problems with NG gas transportation by pipelines in the EU, there is also a concern with a shortage risk due to external geopolitical conflicts. The main concern is the Russian-Ukrainian conflict, which, during the 2014 crisis, reminded the NG flow disruptions occurred in 2006 and 2009. The most serious disruption was that of January 2009, when transit via Ukraine was stopped for almost 2 weeks. Although the Nord Stream, which connects the supply directly from Russia to Germany via the Baltic Sea, was inaugurated in November 2011 to transit via Ukraine due to the concern for such issues, the concern for the high dependency on Russian NG has only intensified. The NG imports to the EU from Russia through Ukraine have decreased from $65 \%$ in 2010 to $50 \%$ in 2013 [79]. However, the Russian natural gas dependency increased from 30.1\% to 39.3\% in the same period [78].

There was also another project to bypass Ukraine in the transport of NG from Russia to the EU, through the Black Sea. The South Stream project, which started in December 2012, was abandoned by the Russian President's decision in December 2014 due to obstacles set by Bulgaria and the EU [80]. Nonetheless, Russia has decided to replace that project with the Turkish Stream, which will also connect Russia with the EU through Turkey, with delivery starting in December 2016 [81]. Although these alternatives avoid the shortage risk resulting from Russian-Ukrainian conflicts, the high dependency on Russian NG presents a high risk to the EU in the event of a socio-political crisis with Russia or with Gazprom (the majority owner of the natural gas supply infrastructure from Russia to Europe).

For all of the above reasons, the EU has taken measures to prevent and mitigate the risks of NG disruption events, such as the issuing of directives imposing obligations on the Member States to maintain minimum stocks, pursue more diversified imports (including LNG) and develop greater connections between the Member States and their LNG terminals in ports. Recent research and simulations on possible NG disruptions from important suppliers in the EU suggest that LNG terminals play an important role in the security of supply and diversification $[82,83]$. For this reason, the EU is now better prepared for a Russian NG supply disruption, and Russia would be more affected due to the loss of revenue for Gazprom [84,85]. In a hypothetical disruption of Russian NG via Ukraine in 2015, only Ukraine would be significantly affected, as its natural gas consumption would be reduced by approximately 50\%. In Bulgaria, Hungary and Romania, it would be reduced by approximately 35\%, whereas in the rest of the Member States, the reduction would be approximately 4\% [82]. In the case of a Gazprom disruption or a total interruption of the Russian NG flow in 2015, the effect would be similar in the Ukraine, but it would be stronger in the EU, with the consumption reduction being approximately $13 \%$. The NG price changes would be similar to the variation in consumption. The price increases during the Ukrainian disruption would be greater than $80 \%$ in Ukraine, Hungary, Serbia, Romania and Bulgaria, whereas in the rest of the Member States, the prices would not be affected. In the Gazprom disruption, the prices would increase by approximately $23 \%$ in every Member State [82].

In the previous scenarios, the LNG terminals have been considered to compensate for the Russian NG disruption, as they have enough installed capacity in ports to cover the total EU NG consumption. However, the limited transport infrastructure from the countries with LNG terminals to the inner Member States does not allow there to be scenarios with zero effect on the EU. For example, the utilization rate of the LNG terminals in Spain increases to only 32\% during the Russian NG disruption scenarios because the NG transport from the Spanish terminals to Central Europe is limited to the capacity of the SpanishFrench pipeline, which has an annual capacity of 5 billion $\mathrm{m}^{3}$. It is therefore necessary to expand the gas interconnections to those countries with LNG terminals to supply the Central and Eastern Member States [82].

A similar situation would occur in the case of an Algerian supply disruption, where the main countries affected would be Greece, Portugal and Spain, due to the low NG reserve levels and limited interconnection with other Member States that could cover their needs during the shortage [83]. 
Despite the above scenarios, the effects of possible supply interruptions of NG in the EU would only be important in the short term because with the framework established by the European Commission to diversify the NG sources as LNG suppliers and develop the transport infrastructure, the Member States could face any short or long NG disruption in the medium and long term successfully [82-85].

The NG supply is also secured in the long term due to the worldwide conventional NG reserves that are approximately 185.7 trillion $\mathrm{m}^{3}$, enough for 55.1 years [86]. The NG reserves, including the commercially exploitable non-conventional sources (shale gas, tight gas and coal bed methane), would be 638 trillion $\mathrm{m}^{3}$, and including the other non-conventional sources such as aquifer gas and methane hydrates (Japan's methane hydrate R\&D program is expected to initiate commercial production by the end of 2018) $[87,88]$, the amount would increase to 845 trillion $\mathrm{m}^{3}$ [89]. As a result, the European NG market would have supplier diversity, increasing energy security and ensuring competitive prices. Moreover, to receive LNG from different suppliers by sea, Europe has 29 regasification terminals in operation. As 23 of them, in 2014, worked at an average of $16 \%$ of their installed capacity, there is enough import potential, not even considering the 8 terminals under construction and the 28 more that are planned to be built [90,91].

However, if new terminals are planned to be installed near settlements or in protected natural areas, environmental groups may block or delay the construction of these infrastructures, mainly arguing potential safety hazards [92]. Similarly, in exporting countries some extracting methods, such as fracking and methane hydrates extraction from beneath the ocean floor, still generate controversy for their environmental risks. Also controversial is the threat to indigenous communities by the expansion of the oil and gas industry.

Despite the above, Marcogaz [93] argued that the natural gas industry has better records for sustainability aspects in comparison with other fossil fuels. The EU could improve and ensure the compliance with safety standards and respect for the environment and society, both in the construction of the infrastructure and in the selection of LNG suppliers.

\subsection{Uptake of technology}

In countries that are more experienced with LNG vehicles such as the U.S., despite there being a strong fuel supply security, established regulations and incentives for fleet owners for using LNG-fueled trucks, the customers are still concerned about the adoption of this new technology. In addition to the same problem about the lack of refueling infrastructure, another concern in the use of LNG in HDVs is the imperfect information obtained from trucking firms about the fuel savings and maintenance costs. The fleet owners do not trust the manufactures' and dealers' quantitative estimations because real fuel savings depends on the tires, road, load, weather conditions and especially the driver behavior. For that reason, to verify the durability and good performance of these innovations, most fleet owners prefer to carry out their own tests, and companies with fewer resources may wait 1-2 years for the results of tests carried out by their partners or competitors before adopting new technologies [72]. Another reason for carrying out their own tests is to wait for driver acceptance of the new technology. Fleet managers might not adopt a new technology if it requires excessive driver training or behavior changes. The driver acceptance is related to split incentives, identified as a market failure [72] because, in some cases when the new fuelsaving technology does not bring benefit to the driver, unless they receive a bonus or extra pay for the efficient driving, technology is not well received by drivers. For that reason, the LNG-fueled truck manufacturers must ensure that the new vehicles have the same or more comfort and safety conditions for the driver and a good after-sales service and also provide systems that facilitate fuel consumption control and easy driving. Another split incentive is present in the resale market, where new fuel saving technologies are not valued because the buyers are not aware of the benefits of the new technology, and in many cases, they buy the truck for use in different activities, or the people who are responsible for the purchase are not responsible for the fuel expenses in the company [72].

Additionally, despite the recent reliance in the U.S. on their own NG production and reserves, which consequently could provide LNG price stability in the future, fleet owners and operators are still concerned due to the fuel price uncertainty, as the truck investment might be not sustainable in the case of a high LNG price increase. This situation would be of greater concern to European fleet owners due to the small local NG reserves and production, forcing them to rely on NG imports.

Other aspects identified by fleet owners as potential barriers to new technologies are customer's concerns [72]. Many people know the negative environmental impact of diesel combustion, especially air pollutants, but few of them know the LNG combustion benefits in the air quality. In addition, there is an associated fear with the perception on the danger of NG vehicles and refueling stations [40]. For instance, in some underground intermodal terminals in Spain the access to NG buses is restricted, even though 
there is no specific legislation to restrict them; probably by baseless prejudices such as risks of explosion of fuel tanks or poisoning by inhalation of gas leaks [40]. LNG has fewer environmental and health risks compared to gasoline or diesel; although it can cause suffocation by oxygen displacement, natural gas is non-toxic and dissipates quickly when released $[16,40,94]$. These safety issues are unlikely and currently LNG vehicles can be as safe as diesel vehicles $[26,37,73,94]$. For these reasons, the social acceptance of these NG technologies can be affected by the lack of information in the community, interrupting the development of this market.

\section{Impact on the EU market: the Spanish case}

Spain has special opportunities for growth in LNG use in road freight transport. The infrastructure developed in Spain to import LNG, where there are 7 LNG terminals in operation and 2 under construction [91], provides the advantage of supplying the LNG at service stations at lower prices than those of diesel oil because the NG can be transported directly in the liquid state from the LNG terminal to the station by tanker truck. In addition, there are 17 public LNG filling stations in operation in Spain[50]. Another opportunity in the Spanish market for LNG introduction is the antiquity of its fleet and the current economic recovery. After the 2008 financial crisis, the registration of new HDVs, especially tractor units (long-haul trucks), fell sharply. Consequently, from 2008 to 2013, the total fleet size decreased by $14 \%$, and the average age grew from 6.7 to 9.4 years [95]. This situation, in addition to government incentives to renew the fleets, has led the Spanish long-haul fleet to experience a growth of $1.8 \%$ in 2014, and this trend is expected to persist upon including LNG trucks in the new registrations [96]. The number of LNG-fueled trucks in Spain, despite the financial crisis, has grown quickly since 2011, from less than 10 units to 90 units in 2012, 180 units in 2013 and 306 units in 2014 [50,97].

According to a report developed by Deloitte for the Spanish Association of Natural Gas for Mobility (GASNAM), the intercity LNG-fueled fleet could share approximately $45 \%$ of this market in Spain by 2045 [40]. Based on these trends and projections, considering the market introduction of high efficiency dual-fuel HPDI trucks [16,49] and an average distance covered annually of approximately $120000 \mathrm{~km}$ [98], the GHG emissions produced by the operation of the Spanish articulated long-haul trucks would be reduced by approximately $12 \%$ (3.7 $\mathrm{Mt} \mathrm{CO}_{2}$-eq) by 2045, Fig. 3 .

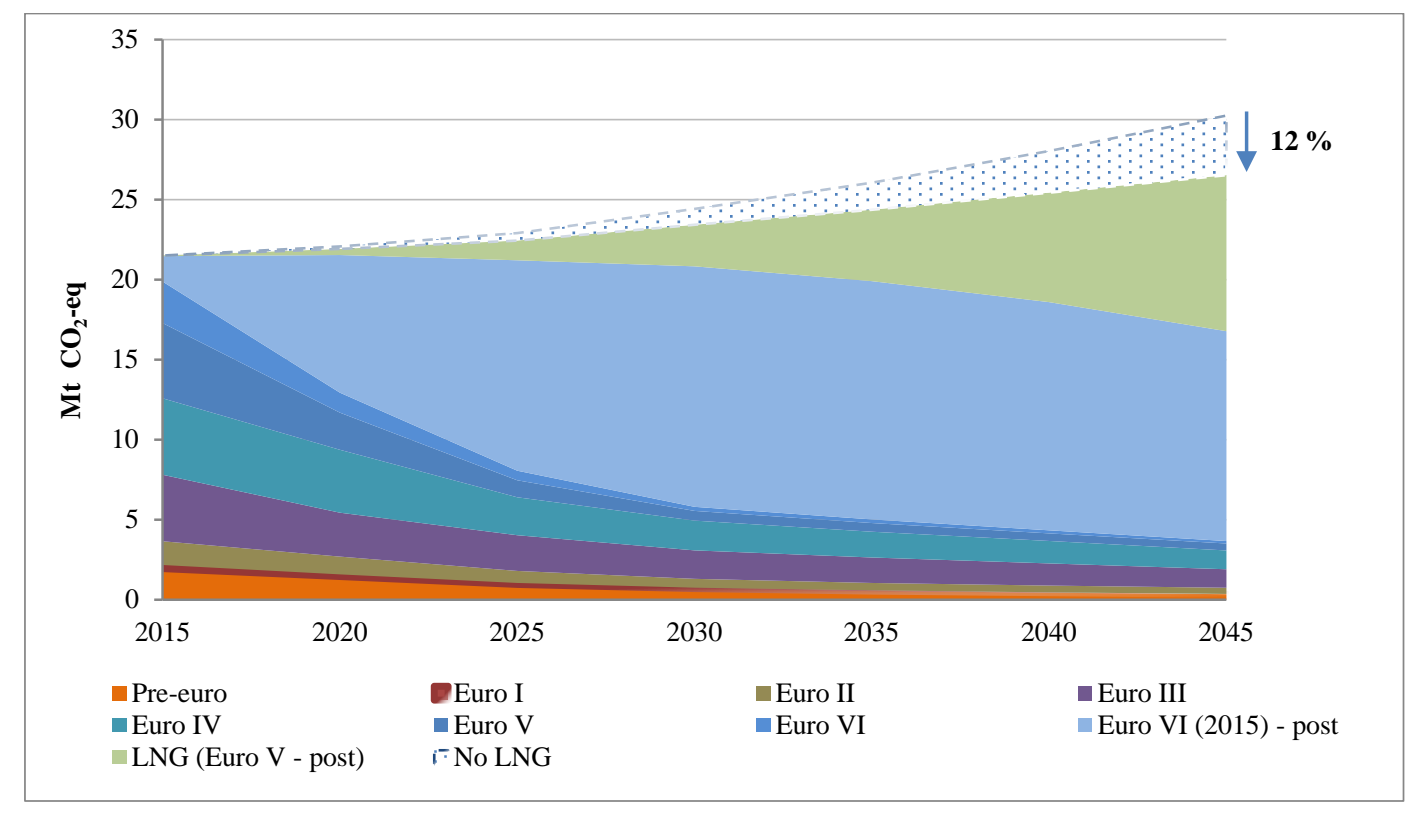

Fig. 3. Tank-to-Wheels GHG emissions by Spanish long-haul trucks.

Sources: author's estimations based on data from [29,38,40,44,49,95-97,99,100]

In Fig. 3, the green area shows the GHG emitted by LNG trucks, reducing pollution compared with the scenario without LNG trucks. In the scenario without LNG, the GHG emitted by Euro VI (2015) and post-Euro VI diesel trucks would reach until the blue dashed line. 
This fuel switch to LNG to decrease the GHG emissions is necessary due to the stagnation of the fuel consumption reduction in diesel engines. In the past 25 years, after the European air pollution standard (Euro I-VI) implantation, the fuel consumption in long-haul trucks has not been reduced significantly, remaining approximately 35 liters of diesel for each $100 \mathrm{~km}$ in a partial load [100,101]. As the GHG emissions from CI engines consist of more than $98 \% \mathrm{CO}_{2}$, depending on fuel consumption, the GHG emissions reduction from long-haul trucks has stagnated. Despite manufactures recently achieving improvements in fuel efficiency through methods such as more aerodynamic bodies, single tires, lighter materials, low-viscosity lubricants, and automatic tire inflation, the European air pollution standards have not allowed reducing the fuel consumption. This is because the manufacturers have concentrated their research in both the control and reduction of toxic gases, by modifying the engines and installing devices for exhaust after-treatment, such as exhaust gas recirculation valves and diesel particulate filters, which reduce $\mathrm{NO}_{\mathrm{x}}$ and $\mathrm{PM}$, respectively, but can also affect the fuel efficiency [100,102,103]. Recently, manufactures have demonstrated technology improvements for complying with the Euro VI standard using a selective catalytic reduction system to reduce the $\mathrm{NO}_{\mathrm{x}}$ emissions by adding urea as reductant liquid in the system, obtaining diesel fuel consumption of $28 \mathrm{~L} / 100 \mathrm{~km}$ under optimal road conditions and driving behavior during efficiency tests [104,105]. Therefore, average diesel fuel consumption in diesel Euro VI and post-Euro VI long-haul trucks in real-world conditions of $31 \mathrm{~L} / 100 \mathrm{~km}$ is expected in the next few years.

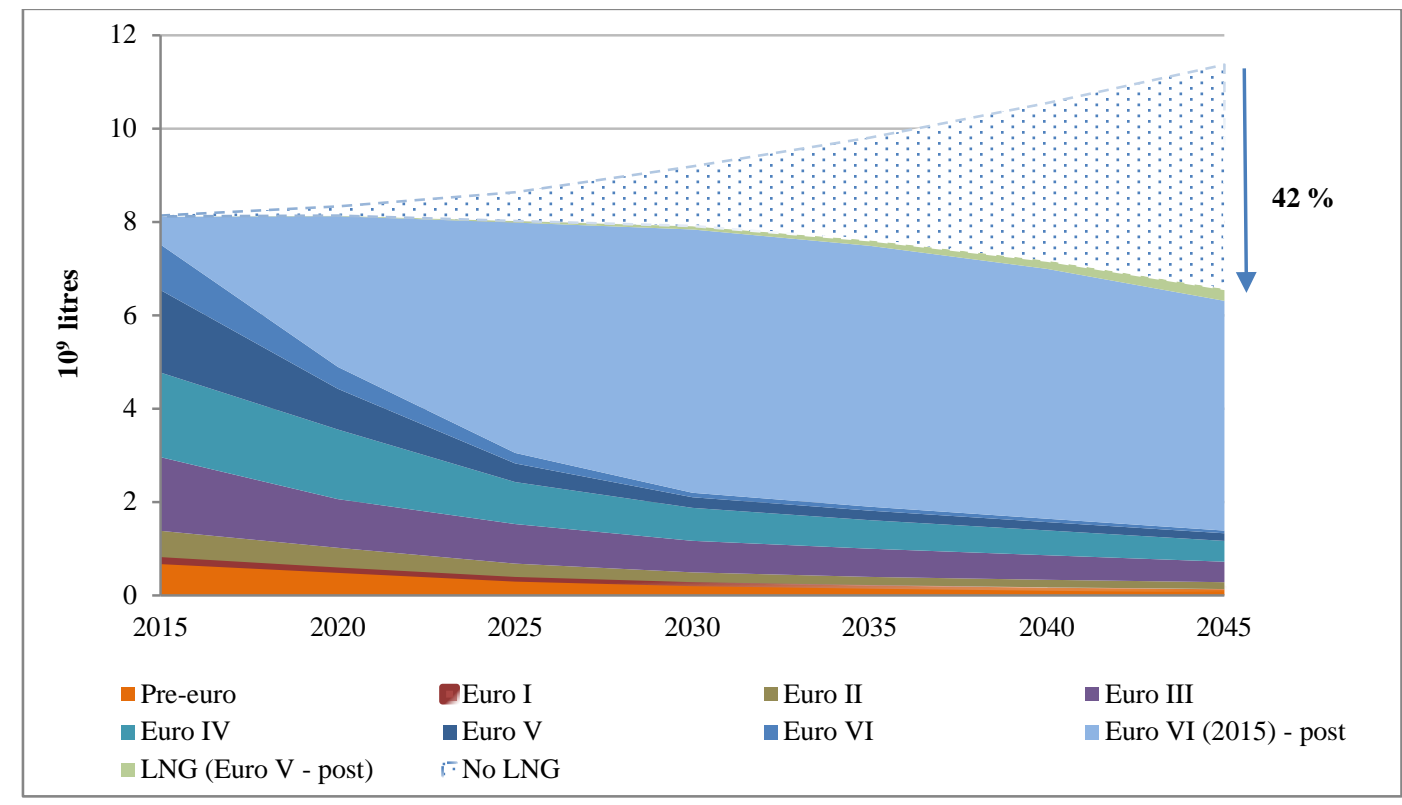

Fig. 4. Tank-to-Wheels diesel fuel consumption by Spanish long-haul trucks. Sources: author's estimations based on data from [29,38,40,44,49,95-97,99,100]

According to these projections, in Fig. 4, the diesel consumption in 2045 would be reduced by $42 \%$ ( 4.8 GL) with the LNG long-haul truck introduction, based on an average $7 \%$ annual write-off and new registrations of approximately 9\% of the total fleet (diesel and LNG trucks) leading to increases in approximately 1.6\% each year, reaching 300000 tractor units by 2045.

The Netherlands and the United Kingdom are other Member States where the LNG use in transport is in a stage of development between demonstration and early market, reporting 387 and 621 LNG trucks at the end of 2014 respectively [50]. However, growth rates are different, which mainly depends on the degree of government support. In Spain, in the last few years the fleet powered by LNG has grown rapidly motivated by the low LNG prices and government incentives such as subsidy of $20000 €$ for each LNG truck as part of the Spanish Strategy to promote Alternative Energy Vehicles [106].

In the Netherlands, the goals set by the National LNG Platform with the Green Deal LNG initiative in 2012 were 500 LNG trucks and 50 LNG stations in operation by 2015 [16]. However, by mid-2015 there were 13 stations [50]. Similarly, the National LNG Platform set a goal of replacing petroleum fuels with 2.5 Mt of LNG by 2025, representing 10-15\% of the diesel used in the transport sector. However Kroon et 
al. (cited in [16]) argued that this goal requires a fleet of 40000 LNG trucks, twice the figure expected in Spain for the same year.

The UK has been a pioneer in testing LNG trucks since 2007, when companies in the transport sector conducted pilot tests with fleets of up to 101 LNG trucks [107]. These tests were co-funded by the Low Carbon Vehicles Innovation Platform as part of a low carbon truck demonstration trial. The motivations of the UK government are the reduction of imported oil dependency, based on its natural gas reserves and the development of biogas production. Although the UK has the largest LNG fleet in the EU, the growth has been slower than for the Spanish and the Dutch markets.

Another country whose government has implemented incentive policies is Sweden through the program BiMe trucks. This program financed about $17000 €$ per LNG truck since 2010, with the aim of mixing up to 50\% with liquefied biogas [108]. However, by the end of 2014 there were only 69 trucks in Sweden, despite having 6 LNG stations [50]. The Italian market also is expected to consolidate. The first LNG station in Italy was recently installed as part of the Blue Corridors Project. Italy, which has the largest number of CNG vehicles in the EU, had only 56 LNG trucks by 2014 [50].

In Germany, despite having large number of CNG trucks, the LNG market is presently under research. German institutions have developed extensive studies such as the DENA report [16], which compared the Dutch market and more developed markets such as the U.S. and China. DLR [38] made projections of the introduction of LNG by 2030, where in a moderate scenario for N3 tractor units, LNG trucks would share $5 \%$, while in an accelerated scenario would be $20 \%$. In the case study for Spain, the share would be $15 \%$ by the same year.

No trends or reliable information on the development of other European markets exist. Poland could develop the LNG market for HDV considering that has introduced this technology in buses, totaling 57 LNG buses by the end of 2014 [50]. There are projections with a wide scope that indicate the penetration of LNG in the European fleets would be 9\% for 2025 [52], while more ambitious projections indicate a $15 \%$ by 2020 [109]. In the case study for Spain, the share for 2020 and 2025 would be 3\% and 8\%, respectively.

\section{Conclusions}

LNG use in heavy-duty trucks for freight transport is possible due to the mature technology and energy resource availability. From an environmental point of view, fuels from renewable sources must always have higher priority than fossil fuels as NG. However, in the case of long-haul road transport, where renewable fuels are not currently a feasible option, using LNG instead of diesel is preferred with regard to sustainability. In addition, the use of natural gas in transport would serve as a transition to the use of biogas in the coming years as long as a large-scale production at competitive prices is reached. Recent studies have shown the LNG introduction in road transport in the EU can reduce the environmental impact and noise in cities; the $\mathrm{SO}_{\mathrm{x}}$ and $\mathrm{PM}$ emissions are almost entirely eliminated and the $\mathrm{NO}_{\mathrm{x}}$ strongly reduced without requiring the use of after-treatment exhaust equipment. The GHG emissions during the LNG truck operation are also reduced by $20 \%$ in terms of the distance travelled. In addition, the fuel efficiency in the subsequent years by long-haul trucks is expected to increase, reaching GHG emissions reductions of approximately $12 \%$ and diesel fuel consumption reduction of approximately $42 \%$ in 2045 for the total fleet of Spain.

Despite the availability of information for the estimation of GHG emissions, albeit scarce, it is still necessary to perform further experimentation to determine emission factors for other gases and toxic particles generated by LNG-fueled trucks, especially in terms of the distance travelled.

The EU has a clear vision encouraging the use of LNG by supporting the service station construction along corridors connecting the Member States. Additionally, the EU's strategy to diversify the NG sources as LNG suppliers, to keep minimum stocks, and developing more connections between the Member States is strengthening the NG market, making the prices more competitive and stable and guaranteeing the security of supply in the face of any outages from its main suppliers.

Governments should promote LNG technology adoption directly to customers through tax reduction, benefits in tolls, reduced import tariffs for conversion kits and new vehicles, and subventions for the local development and manufacture of these technologies. In addition, governments alongside manufacturers and NG traders must intervene to avoid the market failures through awareness campaigns to the general public and fleet owners. The campaigns should provide complete information that takes into account technical, environmental and socioeconomic aspects such as safety and reliability of technology, emission factors, maintenance plans, and training to employees. These measures would allow stakeholders to 
evaluate the actual impact of LNG use in companies and countries, enabling the introduction of a potential alternative to replace traditional fuels in road freight transport in the EU.

\section{References}

[1] European Environment Agency. Greenhouse gas emissions from transport. Copenhagen: 2015.

[2] European Environment Agency. Annual European Union greenhouse gas inventory 1990 - 2013 and inventory report 2015. Copenhagen: 2015.

[3] Andress D, Nguyen TD, Das S. Reducing GHG emissions in the United States' transportation sector. Energy Sustain Dev 2011;15:117-36. doi:10.1016/j.esd.2011.03.002.

[4] Graham L a., Rideout G, Rosenblatt D, Hendren J. Greenhouse gas emissions from heavy-duty vehicles. Atmos Environ 2008;42:4665-81. doi:10.1016/j.atmosenv.2008.01.049.

[5] Beer T, Grant T, Williams D, Watson H. Fuel-cycle greenhouse gas emissions from alternative fuels in Australian heavy vehicles. Atmos Environ 2002;36:753-63. doi:10.1016/S13522310(01)00514-3.

[6] De Simio L, Gambino M, Iannaccone S. Possible transport energy sources for the future. Transp Policy 2013;27:1-10. doi:10.1016/j.tranpol.2013.01.006.

[7] Stodolsky F, Gaines L, Marshall CL, An F, Eberhardt JJ. Total Fuel Cycle Impacts of Advanced Vehicles. SAE Tech Pap Ser 1999. doi:10.4271/1999-01-0322.

[8] Anderson LG. Effects of using renewable fuels on vehicle emissions. Renew Sustain Energy Rev 2015;47:162-72. doi:10.1016/j.rser.2015.03.011.

[9] Salvi BL, Subramanian K a., Panwar NL. Alternative fuels for transportation vehicles: A technical review. Renew Sustain Energy Rev 2013;25:404-19. doi:10.1016/j.rser.2013.04.017.

[10] Durbin DJ, Malardier-Jugroot C. Review of hydrogen storage techniques for on board vehicle applications. Int J Hydrogen Energy 2013;38:14595-617. doi:10.1016/j.ijhydene.2013.07.058.

[11] EEGFTF. Report of the European Expert Group on Future Transport Fuels. 2011.

[12] IEA - International Energy Agency. World Energy Outlook Special Report 2015: Energy and Climate Change. Paris: 2015.

[13] Engerer H, Horn M. Natural gas vehicles: An option for Europe. Energy Policy 2010;38:1017-29. doi:10.1016/j.enpol.2009.10.054.

[14] European Commission. Clean Power for Transport: A European alternative fuels strategy. COM (2013) 17 final. Brussels: 2013.

[15] Muñoz Dominguez M, Rozira de Antonio AJ. Máquinas Térmicas. Madrid: 2014.

[16] DENA-German Energy Agency. LNG in Germany: Liquefied Natural Gas and Renewable Methane in Heavy-Duty Road Transport. Aschersleben: 2014.

[17] IANGV. NGV Global News. A Look Back IANGV Twenty Years Ago 2006. http://www.ngvglobal.com/blog/a-look-back-at-the-iangv-twenty-years-ago-0926\#more-2364.

[18] Kumar S, Kwon HT, Choi KH, Lim W, Cho JH, Tak K, et al. LNG: An eco-friendly cryogenic fuel for sustainable development. Appl Energy 2011;88:4264-73. doi:10.1016/j.apenergy.2011.06.035.

[19] Yeh S. An empirical analysis on the adoption of alternative fuel vehicles: The case of natural gas vehicles. Energy Policy 2007;35:5865-75. doi:10.1016/j.enpol.2007.06.012.

[20] Commission of the European Communities. WHITE PAPER. European policy for 2010: time to decide. Brussels: 2001.

[21] European Commission. EU launches clean fuel strategy. Press release. Brussels: 2013.

[22] European Parliament And The Council Of The European Union. Directive 2014/94/EU on the deployment of alternative fuels infrastructure. Off J Eur Union 2014. 
[23] Fedorova EB, Fedorov V V., Shakhov AD. Promising technology for recovery And use of liquefied natural gas. Chem Pet Eng 2009;45:34-9.

[24] M. Frailey. Development of LNG-Powered Heavy-Duty Trucks in Commercial Hauling. NREL/SR-540-25154. 1998.

[25] Litzke W, Wegrzyn J. Natural Gas as a Future Fuel for Heavy-Duty Vehicles. SAE Tech Pap 2001. doi:10.4271/2001-01-2067.

[26] Kevin Chandler B. Norcal prototype LNG truck fleet: Final Results. 2004.

[27] Peredel'skii V a., Lastovskii Y V., Darbinyan R V., Savitskii a. I, Savitskii a. a. Analysis of the desirability of replacing petroleum-based vehicle fuel with liquefied natural gas. Chem Pet Eng 2005;41:590-5. doi:10.1007/s10556-006-0024-2.

[28] Rideout G, Hendren J. ERMD Report 06-43. Chassis dynamometer evaluation of climate friendly clean air technologies: Westport Power Inc.'s Liquefied Natural Gas Highway Truck Project. Vancouver: 2006.

[29] CARB-California Air Resource Board. Comparison of greenhouse gas emissions from natural gas and diesel vehicles. Report 08/10/2008 n.d.:1-8.

[30] ANL-Argonne National Laboratory. The Greenhouse Gases, Regulated Emissions, and Energy Use in Transportation Model 2014. https://greet.es.anl.gov/ (accessed May 20, 2015).

[31] Rosenfeld J, Jackson MD. Life-Cycle Cost Model and Pollutant Emissions Estimator. Report prepared for Westport Innovations Inc. \& TIAX LLC 2008.

[32] Eric Meloche, Rosenblatt D, Rideout G, Morgan C. ERMS Report 13-16. Emissions Characterization of Diesel and Liquefied Natural Gas Transport Trucks. Vancouver: 2013.

[33] Cheenkachorn K, Poompipatpong C, Ho CG. Performance and emissions of a heavy-duty diesel engine fuelled with diesel and LNG (liquid natural gas). Energy 2013;53:52-7. doi:10.1016/j.energy.2013.02.027.

[34] Arteconi a., Polonara F. LNG as vehicle fuel and the problem of supply: The Italian case study. Energy Policy 2013;62:503-12. doi:10.1016/j.enpol.2013.08.016.

[35] Arteconi a., Brandoni C, Evangelista D, Polonara F. Life-cycle greenhouse gas analysis of LNG as a heavy vehicle fuel in Europe. Appl Energy 2010;87:2005-13. doi:10.1016/j.apenergy.2009.11.012.

[36] Ma L, Geng J, Li W, Liu P, Li Z. The development of natural gas as an automotive fuel in China. Energy Policy 2013;62:531-9. doi:10.1016/j.enpol.2013.06.066.

[37] Argonne National Laboratory (ANL). Case Study - Liquefied Natural Gas. 2013.

[38] DLR, IFEU, LBST, DBFZ. LNG as an alternative fuel for the operation of ships and heavy-duty vehicles: Short study in the context of the National Mobility and Fuel Strategy. Munich: 2014.

[39] Joint Research Centre-EUCAR-CONCAWE (JEC collaboration). Well-to-Wheels Analysis of Future Automotive Fuels and Powertrains in the European Context. Well-to-Tank Report. Version 4a. 2014. doi:10.2790/95629.

[40] DTTL- Deloitte Touche Tohmatsu Limited. Desarrollo del gas natural vehicular en España: análisis de beneficios y potencial contribución a la economía nacional. 2014.

[41] Jaffe AM, Dominguez-Faus R, Lee A, Medlock K, Parker N, Scheitrum D, et al. NextSTEPS White Paper: Exploring the Role of Natural Gas in U.S. Trucking 2015. http://steps.ucdavis.edu/files/02-18-2015-NextSTEPS-White-Paper-Natural-Gas-in-US-Trucking18Feb2015-Public-Release.pdf (accessed March 13, 2015).

[42] Eurostat. Sustainable development in the European Union: 2015 monitoring report of the EU Sustainable Development Strategy. 2015th ed. Luxembourg: 2015. doi:10.2785/11549.

[43] Loomis D, Grosse Y, Lauby-Secretan B, Ghissassi F El, Bouvard V, Benbrahim-Tallaa L, et al. The carcinogenicity of outdoor air pollution. Lancet Oncol 2013;14:1262-3. doi:10.1016/S14702045(13)70487-X.

[44] Rolande LCNG. Battle of the trucks 2015. http://www.battleofthetrucks.nl/ (accessed August 23, 2015).

[45] Merkisz J, Jacyna M, Merkisz-Guranowska A, Pielecha J. Exhaust emissions from modes of 
transport under actual traffic conditions. WIT Trans. Ecol. Environ., vol. 190, 2014, p. 1139-50. doi:10.2495/EQ141062.

[46] Lu XS, Gu AZ, Zhang WC. The development of LNG vehicles and the key technologies. Sixth Natl. Conf. Low Temp. Refrig. Eng. (in Chinese), 2003.

[47] Zhou SH, Chen JD, Lu A. The choices of natural gas vehicle development mode in China's coastal regions. Int Pet Econ 2010;4:14-9 (in Chinese).

[48] Westport Power Inc. Westport high pressure direct injection technology 2015. http://www.westport.com/is/core-technologies/combustion/hpdi (accessed November 15, 2015).

[49] AB Volvo. Volvo trucks 2015. http://www.volvotrucks.com/trucks/global/en-gb/trucks/newtrucks/Pages/volvo-fm-methanediesel.aspx (accessed August 2, 2015).

[50] NGVA Europe. Natural \& bio Gas Vehicle Association 2015. http://www.ngva.eu/ (accessed March 29, 2016).

[51] Petroleum Economist. China pushes natural gas as transport fuel 2013. http://www.petroleumeconomist.com/Article/3203481/China-pushes-natural-gas-as-transport-fuel.html (accessed August 15, 2015).

[52] Morse EL, Yuen A, Kleinman SM, Wetherbee C, Thein T, Michaeli I, et al. Energy 2020: Trucks Trains \& Automobiles. 2013.

[53] FERC. Federal Energy Regulatory Commission. World LNG Estim Landed Prices 2015. http://www.ferc.gov/ (accessed March 29, 2016).

[54] European Commission. Taxation and Customs Union 2016. http://ec.europa.eu/taxation_customs/index_en.htm (accessed March 30, 2016).

[55] UNECE. 104th meeting of Group of Experts on General Safety LNG Task Force: LNG Heavy Duty Trucks Case Studies 2013.

[56] Lebrato J. LNG network identification. Deliverable BC D3.7 LNG Blue Corridors Project. 2012.

[57] Zunder TH, Ibanez JN. Urban freight logistics in the European Union. Eur Transp / Trasp Eur 2004;28:77-84.

[58] World Health Organization. Burden of disease from environmental noise. WHO Reg Off Eur 2011. http://www.euro.who.int/_data/assets/pdf_file/0008/136466/e94888.pdf (accessed June 1, 2015).

[59] Kijewska K, Johansen BG. Comparative Analysis of Activities for More Environmental Friendly Urban Freight Transport Systems in Norway and Poland. Procedia - Soc Behav Sci 2014;151:142-57. doi:10.1016/j.sbspro.2014.10.015.

[60] Wild D. Integration of Freight in Urban Pricing Schemes. Second Semin. IMPRINT-EUROPE; "Implementing Reform Transp. Pricing Identifying Mode-Specific issues,” Brussels: 2002.

[61] Suksri J, Raicu R. Developing a Conceptual Framework for the Evaluation of Urban Freight Distribution Initiatives. Procedia - Soc Behav Sci 2012;39:321-32. doi:10.1016/j.sbspro.2012.03.111.

[62] Quak HJ, Koster MBM De. Urban Distribution: The Impacts of Different Governmental TimeWindow Schemes. ERIM Rep Ser Res Manag 2006.

[63] Stathopoulos A, Valeri E, Marcucci E. Stakeholder reactions to urban freight policy innovation. J Transp Geogr 2012;22:34-45. doi:10.1016/j.jtrangeo.2011.11.017.

[64] Muñuzuri J, Cortés P, Guadix J, Onieva L. City logistics in Spain: Why it might never work. Cities 2012;29:133-41. doi:10.1016/j.cities.2011.03.004.

[65] Korakianitis T, Namasivayam a. M, Crookes RJ. Natural-gas fueled spark-ignition (SI) and compression-ignition (CI) engine performance and emissions. Prog Energy Combust Sci 2011;37:89-112. doi:10.1016/j.pecs.2010.04.002.

[66] Tilagone R, Monnier G, Chaouche A. Development of a High Efficiency, Low Emission SICNG Bus Engine. SAE Tech Pap Ser 1996. doi:10.4271/961080.Ga.

[67] Kakaee AH, Paykani A. Research and development of natural-gas fueled engines in Iran. Renew Sustain Energy Rev 2013;26:805-21. doi:10.1016/j.rser.2013.05.048. 
[68] Abdelaal MM, Hegab a. H. Combustion and emission characteristics of a natural gas-fueled diesel engine with EGR. Energy Convers Manag 2012;64:301-12. doi:10.1016/j.enconman.2012.05.021.

[69] Mercedes-Benz España S.A. Mercedes-Benz España entrega la primera tractora Econic GNL a Acotral 2009. http://www.mercedes.es/actualidad/noticias/news3.asp?NoNews=1718 (accessed March 18, 2015).

[70] Heraldo de Arangón Editora Digital SL. Simply invierte 2 millones de euros en su plataforma logística de Villanueva 2014. http://www.heraldo.es/noticias/aragon (accessed March 18, 2015).

[71] Li W, Dai Y, Ma L, Hao H, Lu H, Albinson R. Oil-saving pathways until 2030 for road freight transportation in China based on a cost-optimization model. Energy 2015;86:369-84. doi:10.1016/j.energy.2015.04.033.

[72] Klemick H, Kopits E, Wolverton A, Sargent K. Heavy-duty trucking and the energy efficiency paradox: Evidence from focus groups and interviews. Transp Res Part A Policy Pract 2015;77:154-66. doi:10.1016/j.tra.2015.04.004.

[73] UNECE. Informal Document for the 104th meeting of Group of Experts on General Safety United Nations. LNG Heavy Duty Truck Case Stud 2012. http://www.unece.org/fileadmin/DAM/trans/doc/2013/wp29grsg/GRSG-104-32e.pdf (accessed October 25, 2015).

[74] Neumann A. Linking Natural Gas Markets - Is LNG Doing Its Job? Discuss Pap DIW Berlin 2008.

[75] Barnes R, Bosworth R. LNG is linking regional natural gas markets: Evidence from the gravity model. Energy Econ 2015;47:11-7. doi:10.1016/j.eneco.2014.10.004.

[76] Bianco V, Scarpa F, Tagliafico L a. Current situation and future perspectives of European natural gas sector. Front Energy 2015;9:1-6. doi:10.1007/s11708-014-0340-8.

[77] International Energy Agency. Medium-Term Gas Market Report 2015. Paris: 2015. doi:10.1787/mtrgas-2015-en.

[78] European Commission. Eurostat Statistics Explained. Energy Prod Imports 2015. http://ec.europa.eu/eurostat/statistics-explained/index.php/Energy_production_and_imports (accessed August 20, 2015).

[79] IEA - International Energy Agency. Facts in Brief: Russia, Ukraine, Europe, Oil and Gas 2014. http://www.iea.org/media/news/20140304UkraineRussiaEuropegasoilfactsheet.pdf (accessed August 19, 2015).

[80] Gotev G. Putin: We haven't given up the South Stream project 2015. http://www.euractiv.com/sections/energy/putin-we-havent-given-south-stream-project-312224 (accessed August 21, 2015).

[81] RT news. Talks on Turkish Stream on hold till November - media 2015. http://www.rt.com/business/311447-russia-turkey-pipeline-talks/ (accessed August 5, 2015).

[82] Richter PM, Holz F. All quiet on the eastern front? Disruption scenarios of Russian natural gas supply to Europe. Energy Policy 2015;80:177-89. doi:10.1016/j.enpol.2015.01.024.

[83] Flouri M, Karakosta C, Kladouchou C, Psarras J. How does a natural gas supply interruption affect the EU gas security? A Monte Carlo simulation. Renew Sustain Energy Rev 2015;44:78596. doi:10.1016/j.rser.2014.12.029.

[84] Hecking H, John C, Weiser F. An Embargo of Russian Gas and Security of Supply in Europe. Zeitschrift Für Energiewirtschaft 2015;39:63-73. doi:10.1007/s12398-014-0145-9.

[85] Behrens A, Wieczorkiewicz J. Is Europe vulnerable to Russian gas cuts? CEPS Comment 12 March 2014 2014:1-4.

[86] British Petroleum. BP Statistical Review of World Energy. London: 2014.

[87] MH21. Phase 1 Comprehensive report of research results 2011. http://www.mh21japan.gr.jp/english/wp/wpcontent/uploads/ca434ff85adf34a4022f54b2503d86e92.pdf (accessed March 30, 2015).

[88] Lu S-M. A global survey of gas hydrate development and reserves: Specifically in the marine field. Renew Sustain Energy Rev 2015;41:884-900. doi:10.1016/j.rser.2014.08.063. 
[89] BGR. Energy Study 2014. Reserv. Resour. Availab. energy Resour., vol. 18, Hannover: 2014, p. 131.

[90] Nikodym M. Developing infrastructure to support the market for LNG as a fuel. Eur. LNG Strateg., London: 2015.

[91] GIE - Gas Infrastrucure Europe. GIE LNG Map 2015. http://www.gie.eu/index.php/mapsdata/lng-map (accessed August 8, 2015).

[92] Coequyt J, Albrecht K. Liquid Natural Gas: A roadblock to a clean energy future. Washington, D.C: 2004.

[93] Marcogaz. The Natural Gas Industry in Europe: key factors for a successful sustainable energy future. MARCOGAZ Sustain Rep 2008. http://www.marcogaz.org/index.php/environmenthealth-a-safety (accessed March 11, 2016).

[94] Brecher A, Epstein AK, Breck A. Review and Analysis of Potential Safety Impacts of and Regulatory Barriers to Fuel Efficiency Technologies and Alternative Fuels In Medium- and Heavy-Duty Vehicles. (Report No. DOT HS 812 159). Washington, D.C: 2015.

[95] ANFAC - Asociación Española de Fabricantes de Automóviles y Camiones. Anfac Research 2013. http://www.anfac.com/openPublicPdf.action?idDoc=8175 (accessed August 12, 2015).

[96] DGT. Dirección General de Tráfico 2015. http://www.dgt.es/es/explora/en-cifras/parque-devehiculos.shtml (accessed August 2, 2015).

[97] GASNAM. Asociación Ibérica de Gas Natural para la Movilidad 2015. http://gasnam.es/1451-2/ (accessed August 8, 2015).

[98] Ministerio de Fomento - MFOM. Observatorio de Costes del Transporte de Mercancías por Carretera 2015. http://www.fomento.gob.es/MFOM.CP.Web/handlers/pdfhandler.ashx?idpub=TTW015 (accessed August 8, 2015).

[99] Ntziachristos L, Samaras Z. Exhaust emissions from road transport. EMEP/EEA Emiss. Invent. Guideb. 2013. update Sep, Luxembourg: 2014.

[100] Dünnebeil F, Lambrecht U. Fuel efficiency and emissions of trucks in Germany - an overview. 2012.

[101] TU Graz. Reduction and Testing of Greenhouse Gas Emissions from Heavy Duty Vehicles - LOT 2. vol. 43. Graz: 2012.

[102] Benajes J, Pastor J V., García A, Monsalve-Serrano J. The potential of RCCI concept to meet EURO VI NOx limitation and ultra-low soot emissions in a heavy-duty engine over the whole engine map. Fuel 2015;159:952-61. doi:10.1016/j.fuel.2015.07.064.

[103] Akkermans L, Leuven M. GHG reduction measures for the Road Freight Transport sector 2014.

[104] Buchholz T, Schweikl T. best of 9 2015. http://www.bestof9.eu/ (accessed August 15, 2015).

[105] Cnh Industrial. Iveco $\quad$ España, 2015. http://www.iveco.com/spain/empresa/pages/record_consumo.aspx (accessed August 15, 2015).

[106] Spanish Government. Real Decreto 1078/2015, de 27 de noviembre, por el que se regula la concesión directa de ayudas para la adquisición de vehículos de energías alternativas, y para la implantación de puntos de recarga de vehículos eléctricos en 2016, MOVEA. Spain: BOE; 2015.

[107] Fevre C Le. The Prospects for Natural Gas as a Transport Fuel in Europe. vol. 84. 2014.

[108] Energigas Sverige. The Swedish Gas Association - for an increased use of gas energy in Sweden. 2015. http://www.energigas.se/In-English (accessed March 23, 2016).

[109] Cardwell D, Krauss C. Trucking Industry Is Set to Expand Its Use of Natural Gas. New York Times 2013. 


\section{Table Captions}

Table 1

Literature review related to LNG application in road freight transport.

\section{Figure Captions}

Fig. 1. Life-cycle GHG emissions comparison in LNG and diesel HDVs. Sources: [16,29-31,35,38].

Fig. 2. Diesel and LNG costs breakdown

Fig. 3. Tank-to-Wheels GHG emissions by Spanish long-haul trucks.

Sources: author's estimations based on data from [29,38,40,44,49,92-94,96,97]

Fig. 4. Tank-to-Wheels diesel fuel consumption by Spanish long-haul trucks.

Sources: author's estimations based on data from [29,38,40,44,49,92-94,96,97] 